\title{
PENGARUH PROMOSI KESEHATAN DENGAN MEDIA VIDEO EDUKASI TERHADAP TINGKAT PENGETAHUAN DAN SIKAP CUCI TANGAN PAKAI SABUN PADA PENGASUH BALITA SEBAGAI UPAYA PENCEGAHAN DIARE \\ Studi Dilakukan Wilayah Kerja UPTD Puskesmas I Dinas Kesehatan Kecamatan Denpasar Selatan
}

\author{
Ayu Made Rahayuni ${ }^{1}$, Ni Ketut Rusminingsih ${ }^{2}$
}

\begin{abstract}
Habit of washing hands with soap is part healthy lifestyle which is one three pillars development in health sector, namely healthy living habits. Video is a set of tools that can project a moving image which is a combination of image and sound to form the same character as the original object. From results surveys that researchers have done before, researchers are again interested in taking this research, researchers are really looking at effect health promotion methods through educational videos about application hand washing with soap. The purpose of this study is to determine effect health promotion with educational video media on the level of knowledge and attitude washing hands with soap in caregivers of toddlers as an effort to prevent diarrhea. Research method used is pre-experimental research with One Group Pretest Posttest Design. With the results of data analysis obtained using the paired t-test, sig (2-tailed) (0.000) < (0.05). So it can be concluded that effect health promotion with educational video media can increase the knowledge and attitude of washing hands with soap in caregivers toddlers, it is recommended as input for health promotion program planners about education for hand washing with soap as an effort to prevent diarrhea.
\end{abstract}

Keywords: Health Promotion, Knowledge, Attitude, Diarrhea

\section{PENDAHULUAN}

Pembangunan kesehatan merupakan salah satu bagian integral dari pembangunan nasional yang mempunyai peranan besar dalam menentukan keberhasilan pencapaian tujuan pembangunan nasional.Pembangunan kesehatan yang dilakukan dapat meningkatkan kualitas sumber daya manusia yang ditandai dengan tingkat kesehatan penduduk yang meningkat ${ }^{1}$. PHBS merupakan bagian dari upaya peningkatan promotif kesehatan dan pencegahan (preventif) penyakit. Pelaksanaan program Perilaku Hidup Bersih dan Sehat dikelompokkan menjadi 5 tatanan yaitu PHBS di 
Sekolah, PHBS di Rumah Tangga, PHBS di Institusi Kesehatan, PHBS di Tempat-tempat umum dan PHBS di Tempat Kerja. Dari kelima tatanan tersebut tatanan sekolah merupakan tatanan awal untuk membentuk sumber daya yang sehat dan berkualitas $^{2}$.

Kebiasaan mencuci tangan dengan sabun, adalah bagian dari perilaku hidup sehat yang merupakan salah satu dari tiga pilar pembangunan bidang kesehatan yakni perilaku hidup sehat, penciptaan lingkungan yang sehat serta penyediaan layanan kesehatan yang bermutu dan terjangkau oleh semua lapisan masyarakat ${ }^{1}$.

Menurut Susilana dan Siyani yang dimana, Video penyuluhan adalah media audio-visual yang digunakan untuk memberikan pendidikan kepada masyarakat luas. video digunakan sebagai media penyuluhan karena dapat memberikan pesan yang dapat diterima secara merata, lebih realistis, dapat diulang-ulang dan dihentikan sesuai kebutuhan dapat memengaruhi sikap yang menonton, serta sangat bagus untuk menerangkan proses ${ }^{3}$
Dari hasil survey yang sudah pernah peneliti lakukan sebelumnya , peneliti kembali tertarik untuk mengambilan penelitian ini, peneliti sangat ingin melihat pengaruh metode promosi kesehatan melalui video edukasi tentang penerapan cuci tangan pakai sabun dengan melihat pengetahuan dan sikap pengasuh balita apakah sudah memahami untuk selalu menerapkan perilaku hidup bersih dan sehat terutamanya pada perilaku cuci tangan pakai sabun yang harus selalu dilakukan sebagai pencegahan diare pada balita.Penyuluhan dengan menggunakan media video ini diharapkan untuk bisa meningkatkan pengetahuan dan sikap pengasuh balita dalam menerapkan perilaku hidup bersih dan sehat.Tujuan penelitian untuk mengetahui pengaruh promosi kesehatan dengan media video edukasi terhadap tingkat pengetahuan dan sikap cuci tangan pakai sabun pada pengasuh balita sebagai upaya pencegahan diare. 


\section{METODE PENELITIAN}

Jenis penelitian yang digunakan adalah penelitian praeksperimen dengan rancangan One Group Pretest PosttestDesign.

\begin{tabular}{|lcr|}
\hline Pretest & Perlakuan & Posttest \\
\hline $\mathbf{0 1}$ & $\mathbf{X}$ & $\mathbf{0 2}$ \\
\hline
\end{tabular}

Dalam penelitian ini yang menjadi sampel penelitian adalah seluruh responden yaitu pengasuh balita yang membawa balita untuk berobat ke UPTD Puskesmas I Dinas Kesehatan Kecamatan Denpasar Selatan dari bulan Januari sampai bulan Agustus tahun 2020 dengan keluhan diare sebanyak 50 orang. Untuk teknik pengumpulan data dengan wawancara, data observasi dan data kasus diare .Dalam analisis ini dilakukan dengan pengujian statistik yaitu dengan uji paired $t$ test, pada penelitian ini menggunakan taraf signifikan 5\% $(0,05)^{4}$. Sebelum melakukan uji paired t-test sebelumnya dilakukan uji normalitas yang digunakan adalah uji Shapiro-Wilk. Pengujian normalitas data taraf signifikansi yang digunakan adalah 0,05. Jika nilai pada kolom sig. dari hasil uji di SPSS lebih besar dari taraf signifikansi maka data tersebut berdistribusi normal dan sebaliknya lebih kecil dari taraf signifikansi maka data tersebut tidak berdistribusi secara normal ${ }^{5}$.

\section{HASIL DAN PEMBAHASAN}

1. Pengaruh promosi kesehatan dengan media video edukasi terhadap tingkat pengetahuan cuci tangan pakai sabun pada pengasuh balita sebagai upaya pencegahan diare

Tabel 1

Nilai rata-rata tingkat pengetahuan pengasuh balita tentang cuci tangan pakai sabun

\begin{tabular}{|c|c|c|c|c|}
\hline Variabel & Mean & $\mathbf{t}$ & $\begin{array}{c}\text { Sig } \\
\text { (2-tailed) }\end{array}$ & $\mathbf{N}$ \\
\hline Pengetahuan & & & & \\
\hline $\begin{array}{l}\text { Sebelum pemberian } \\
\text { promosi kesehatan dengan } \\
\text { media video edukasi } \\
\text { (pretest) }\end{array}$ & 10,60 & $-2,208$ & 0,032 & 50 \\
\hline $\begin{array}{l}\text { Sesudah pemberian } \\
\text { promosi kesehatan dengan } \\
\text { media video edukasi } \\
\text { (posttest) }\end{array}$ & & & & 50 \\
\hline
\end{tabular}


Dari hasil analisis dengan paired $t$ test pada tabel diatas diperoleh hasil nilai rata-rata (mean) pengetahuan pengasuh balita tentang cuci tangan pakai sabun sebagai pencegahan diare sebelum diberikan promosi kesehatan dengan metode video edukasi adalah 9,76 dan setelah diberikan promosi kesehatan dengan metode video edukasi sebesar 10,60 dengan thitung $-2,208$ serta nilai sig (2-tailed) sebesar 0,032. Dengan melihat sig (2-tailed) $(0,032)<$ alpha $(0,05)$ maka ada pengaruh promosi kesehatan dengan media video edukasi terhadap tingkat pengetahuan cuci tangan pakai sabun pada pengasuh balita sebagai upaya pencegahan diare. Pengetahuan merupakan hasil dari tahu, dan ini terjadi setelah orang melakukan pengindraan terhadap suatu objek tertentu(8). Pengindraan terjadi melalui pancaindra manusia, yakni indra penglihatan, pendengaran, penciuman, rasa, dan raba. Sebagaian besar pengetahuan manusia diperoleh melalui mata dan telinga.Pengetahuan atau ranah kognitif merupakan domain yang sangat penting dalam membentuk tindakan seseorang (overt behaviour). ${ }^{6}$

Media video dalam proses pembelajaran dapat meningkatkan motivasi dan hasil belajar siswa, karena memiliki kemampuan untuk memaparkan sesuatu yang rumit atau kompleks melalui stimulus audio visual yang akhirnya membuahkan hasil lebih baik. Pembelajaran dengan memanfaatkan media video dapat menciptakan pembelajaran menjadi efektif, menyenangkan, dan tidak membosankan sehingga mempercepat proses penyampaian materi kepada siswa. Kelebihan media video, yaitu memudahkan pengajar dalam menyajikan informasi, memiliki daya tarik, dan bersifat interaktif ${ }^{7}$.

Penelitian sejalan dengan Mulyadi (2018), yang mengatakan dimana Hasil penelitian ini menunjukan bahwa nilai signifikansi lebih kecil dari 0,01 ( $\mathrm{p}=0,001<0,01)$, sehingga hipotesis $\mathrm{Ha}$ dalam penelitian ini diterima. Jadi, ada pengaruh sebelum dan sesudah diberikan pendidikan kesehatan dengan media video terhadap tingkat pengetahuan mengenai PHBS kader 
UKS. Selain itu penelitian ini juga sejalan dengan Penelitian ini sejalan dengan penelitian yang dilakukan oleh Edyati (2015), bahwa penyuluhan kesehatan tentang personal hygiene dengan media video memiliki pengaruh terhadap pengetahuan dan sikap personal hygiene siswa SD 1 Kepek, hal ini dapat dilihat dari nilai $\mathrm{p}$ pengetahuan sebesar 0,000 $(\mathrm{p}=0,000<0,05)$.Adanya perubahan

pengetahuan responden $\begin{array}{r}\text { setelah } \\ \text { diberikan penyuluhan } \\ \text { dengan }\end{array}$
menggunakan media video
membuktikan bahwa media video
memberikan pengaruh yang baik
dalam menyampaikan informasi ${ }^{9}$.

2. Pengaruh promosi kesehatan dengan media video edukasi terhadap tingkat sikap cuci tangan pakai sabun pada pengasuh balita sebagai upaya pencegahan diare

Tabel 2

Nilai rata-rata tingkat sikap pengasuh balita tentang cuci tangan pakai sabun

\begin{tabular}{|c|c|c|c|c|}
\hline Variabel & Mean & $\mathbf{t}$ & $\begin{array}{c}\text { Sig } \\
\text { (2-tailed) }\end{array}$ & $\mathbf{N}$ \\
\hline Pengetahuan & & & & \\
\hline $\begin{array}{l}\text { Sebelum pemberian } \\
\text { promosi kesehatan dengan } \\
\text { media video edukasi } \\
\text { (pretest) }\end{array}$ & 9,60 & $-3,157$ & 0,003 & 50 \\
\hline $\begin{array}{l}\text { Sesudah pemberian } \\
\text { promosi kesehatan dengan } \\
\text { media video edukasi } \\
\text { (posttest) }\end{array}$ & 10,76 & & & 50 \\
\hline
\end{tabular}

Berdasarkan hasil analisis dengan uji paired t-test diperoleh nilai rata-rata pengetahuan pengasuh balita tentang cuci tangan pakai sabun sebagai upaya pencegahan diare sebelum diberikan promosi kesehatan dengan metode video edukasi adalah 9,60 dan setelah diberikan promosi kesehatan dengan metode video edukasi sebesar 10,76 dengan $\mathrm{t}$ hitung $-3,157$. Hal ini menunjukkan rata-rata pengetahuan pengasuh balita meningkat setelah diberikannya promosi kesehatan menggunakan metode video edukasi. Berdasarkan hasil analisis dengan uji paired t-test juga menunjukkan bahwa pada pengasuh balita adanya 
pengaruh pemberian promosi kesehatan dengan metode video edukasi terhadap tingkat sikap pengasuh balita sebelum dan sesudah ini dapat dilihat dari sig (2-tailed) $(0,003)<$ alpha $(0,05)$.Dari hasil penelitian telah dilakukan sejalan dengan Fitatul Islamiyah (2017), yang dimana di dapatkan hasil Uji Paired T-Test sikap pretest dan posttest pada kelompok perlakuan, diperoleh nilai $p$ value $0.000(<0.05)$ dan $\mathrm{T}$ 8.758, sedangkan pada kelompok kontrol diperoleh nilai $p$ value $0.000 \quad(<0.05)$ dan T6.550. Selain itu penelitian ini juga sejalan dengan Lestari (2018), yang dimana hasil uji statistik menunjukkan ada perbedaan yang bermakna antara sikap sebelum dengan sesudah edukasi pada kelompok intervensi $(p=0,008)$.

Diantara beberapa faktor yang mempengaruhi pembentukan sikap adalah pengalaman pribadi, kebudayaan, media masa, institusi atau lembaga pendidikan dan lembaga agama, serta faktor emosi dalam diri. Informasi yang diterima melalui media massa dapat meningkatkan pengetahuan dan sikap seseorang sehingga bisa memperbaiki atau merubah perilakunya menjadi lebih baik ${ }^{12}$. Dalam penentuan sikap yang utuh ini, pengetahuan, pikiran, keyakinan, dan emosi memegang peranan penting.Seperti halnya dengan pengetahuan, sikap ini terdiri dari berbagai tingkatan yaitu receiving, responding, valuting, responsible. ${ }^{6}$.Media audiovisual memang dianggap mampu untuk memberikan gambaran secara lebih jelas dan lebih menarik sebagai media untuk menyampaikan pesan penyuluhan kesehatan. Dimana dianggap mampu untuk menyampaikan pesan yang terkandung dalam media dengan baik kepada audience ${ }^{13}$.

\section{SIMPULAN}

Berdasarkan hasil penelitian dan pembahasan yang telah disampaikan, maka dapat disimpulkan adanya ada pengaruh pemberian promosi kesehatan dengan metode video edukasi terhadap tingkat pengetahuan dan sikap pengasuh balita sebelum dan sesudah tentang cuci tangan pakai 
sabun sebagai upaya pencegahan penyakit diare.

\section{SARAN}

Adapun saran yang dapat diberikan oleh peneliti yaitu bagi Puskesmas Denpasar Selatan I sebagai bahan masukan bagi perencana program promosi kesehatan di UPTD Puskesmas I Dinas Kesehatan Kecamatan Denpasar Selatan dan instansi terkait lainnya tentang edukasi cuci tangan pakai sabun sebagai upaya pencegahan diare dan buat peneliti selanjutnya diharapkan untuk mengkaji kembali metode promosi kesehatan lain yang mungkin belum diteliti

\section{DAFTAR PUSTAKA}

1. Purwandari, R. Hubungan antara perilaku mencuci tangan dengan insiden diare pada anak usia sekolah di kabupaten jember. $J$.

Keperawatan 4, 122-130 (2013).

2. Rastini, N. K. PERBEDAAN PENGGUNAAN METODE CERAMAH DENGAN
METODE CERAMAH

KOMBINASI MEDIA

VIDEO TERHADAP

PENGETAHUAN DAN

TINDAKAN CUCI

TANGAN PAKAI SABUN

SISWA. 8, 13-22 (2018).

3. Mawan Rimba, A.

PENGEMBANGAN VIDEO

PENYULUHAN PERILAKU

HIDUP BERSIH DAN

SEHAT (PHBS)

BERMUATAN NILAI

KARAKTER TERHADAP

PENINGKATAN

PENGETAHUAN

MASYARAKAT DALAM

MENANGGULANGI

PENYAKIT DIARE. Pendidik.

Teor. Penelitian, dan

Pengemb. 2, 883-888 (2017).

4. Syofian, S. Metode Penelitian. (PT Fajar Interpratama Mandiri, 2013).

5. Ar Rahman, F. Penerapan

Model Pembelajaran

Demonstrasi Pada Mata

Pelajaran Desain Grafis Untuk

Meningkatkan Hasil Belajar

Kognitif Siswa. (2010).

6. Notoatmodjo. Promosi 
Kesehatan dan Perilaku

Kesehatan. (Rineka Cipta, 2007).

7. Mulyadi. EFEKTIVITAS

PENDIDIKAN

KESEHATAN DENGAN

MEDIA VIDEO TERHADAP

TINGKAT PENGETAHUAN

PERILAKU HIDUP BERSIH

DAN SEHAT. STIKES Suaka

Insa. Banjarmasin 001, (2018).

8. Edyati, L. 'Pengaruh

Penyuluhan Kesehatan

Dengan Media Video

Terhadap Pengatuan Dan

Sikap Personal Hygiene Siswa

Sd Negeri 1 Kepek Pengasih

Kulon Progo. J. Keperawatan

Stikes Aisyiyah 1, 3-19 (2015).

9. Anshor, M. PENGARUH

PENYULUHAN

KESEHATAN

MENGGUNAKAN VIDEO

TERHADAP

PENGETAHUAN DAN

SIKAP REMAJA TENTANG

DIET SEHAT DI MAN 2

MODEL MEDAN TAHUN

2018. (Universitas Sumatera

Utara, 2018).

10. Islamiyah, F. Pengaruh
Promosi Kesehatan Dengan

Video Sikap Remaja Tentang

Pernikahan Dini Di Smp

Negeri 2 Sanden Bantul,

Universitas Aisyiyah.

Universitas 'Aisyiyah

Yogyakarta. (Universitas

'Aisyiyah Yogyakarta., 2017).

11. Lestari, Y. PENERAPAN

MOBILE VIDEO EFEKTIF

MENINGKATKAN

PENGETAHUAN DAN

SIKAP IBU DALAM

MENURUNKAN LAMA

DIARE BALITA DI

WILAYAH PUSKESMAS

KEDATON BANDAR

LAMPUNG. J. Keperawatan

Indones. 21, 34-42 (2018).

12. Wati, R. PROGRAM STUDI

D IV KEBIDANAN

FAKULTAS KEDOKTERAN.

(2011).

13. Yulinda, A. \& Fitriyah, N.

AUDIOVISUAL DALAM

MENINGKATKAN

PENGETAHUAN DAN

SIKAP TENTANG SADARI

DI SMKN 5 SURABAYA

THE EFFECTIVENESS OF

HEALTH EDUCATON 
WITH LECTURE AND

AUDIOVISUAL METHODS

TO IMPROVE

KNOWLEDGE AND
ATTITUDE ABOUT BSE IN

SMKN 5 SURABAYA. $J$.

Promkes 6, 116-128 (2018). 